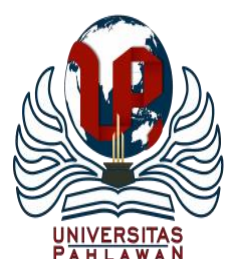

\author{
Jurnal Abdidas Volume 2 Nomor 1 Tahun 2021 Halaman 98-104 \\ JURNAL ABDIDAS \\ http://abdidas.org/index.php/abdidas
}

\title{
Penyuluhan Pembuatan Kreasi Bunga dari Botol Yakult dan Sedotan Plastik
}

\author{
Fita Widiyatun $^{1}$, Sri Endang Wahyuni ${ }^{2}$ \\ Teknik Informatika, Fakultas Teknik dan Ilmu Komputer, Universitas Indraprasta PGRI ${ }^{1,2}$ \\ E-mail: fita.wdy@gmail.com ${ }^{1}$, sherie.endang.wahyuni@gmail.com ${ }^{2}$
}

\begin{abstract}
Abstrak
Berkreasi membuat kerajinan merupakan salah satu kegiatan yang sangat menarik, salah satunya adalah membuat kreasi bunga. Tujuan kegiatan ini adalah melakukan penyuluhan membuat kreasi bunga dari botol yakult dan sedotan plastik. Kreasi bunga yang dibuat adalah bunga lili, bunga tulip, dan pohon kelapa. Peserta pelatihan adalah warga ibu-ibu PKK perumahan Permata Cimanggis, Cluster Mirah, RW 19 dan umum, dengan jumlah peserta sebanyak 18 peserta. Kegiatan pelatihan dilakukan pada tanggal 4 Juli 2020. Metode kegiatan yang digunakan adalah dengan menjelaskan tata cara pembuatan kreasi bunga dengan video dan melakukan tanya jawab. Selain menggunakan video, peserta juga diberikan brosur tata cara pembuatan kreasi bunga untuk membantu peserta dalam membuat kreasi bunga tersebut. Hasil yang diperoleh dari kegiatan ini adalah kegiatan berjalan lancar, serta saat sesi tanya jawab, tidak terdapat pertanyaan dari peserta kegiatan, hal ini menunjukkan bahwa peserta dapat menerima penjelasan tentang pembuatan kreasi bunga lili, tulip, dan pohon kelapa dengan baik.
\end{abstract}

Kata kunci: kreasi bunga, botol yakult, sedotan plastik

Abstract

Creating crafts is one of the most interesting activities, one of which is making flower creations. The aim of this activity is to provide counseling on making flower creations from yakult bottles and plastic straws. Flower creations made are lilies, tulips, and coconut trees. The training participants were residents of the PKK housing Permata Cimanggis Cluster Mirah RW 19 and the general public, with a total of 18 participants. The training activity was carried out on July 4, 2020. The activity method used was to explain the procedure for making flower creations with videos and conduct questions and answers. In addition to using videos, participants were also given brochures on how to make flower creations to assist participants in making these flower creations. The results obtained from this activity were that the activity ran smoothly, and during the question and answer session, there were no questions from the activity participants, this indicated that the participants could receive an explanation of the making of lilies, tulips and coconut tree creations well.

Keywords: flower creations, yakult bottles, plastics straws

Copyright (c) 2021 Fita Widiyatun, Sri Endang Wahyuni

$\triangle$ Corresponding author

Address : Universitas Indraprasta PGRI

Email : fita.wdy@gmail.com

ISSN 2721- 9224 (Media Cetak)

DOI $\quad$ https://doi.org/10.31004/abdidas.v2i1.224

ISSN 2721- 9216 (Media Online) 


\section{PENDAHULUAN}

Berkreasi merupakan suatu kegiatan yang sangat menarik. Kreasi dan kreatifitas dapat dilakukan dari barang/benda yang masih layak guna atau benda yang sudah tidak berguna, yaitu dengan cara mendaur ulang barang yang sudah tidak terpakai.

Sampah terbagi menjadi dua macam, sampah organik dan sampah anorganik. Besar sampah organik di Indonesia sekitar 60\% - 70\%, yang sangat potensial untuk diubah menjadi kompos (Satori et al., 2018). Sedangkan sampah anorganik, perlu adanya suatu kekreatifitasan yang dapat merubah barang-barang tersebut menjadi barang yang bernilai guna, baik untuk mengurangi total sampah, maupun dapat bernilai suatu keindahan dan bernilai ekonomi. Sampah anorganik yang paling banyak ditemukan adalah sampah plastik. Pada tahun 2008, jumlah produksi sampah plastik kemasan mencapai 925.000 ton dan 80\%-nya berpotensi menjadi sampah yang berbahaya untuk lingkungan (Putra \& Yuriandala, 2010).

Harmawati pernah melakukan sosialiasi tentang perilaku hidup bersih dengan menerapkan reduce, reuse, dan recycle (Harmawati et al., 2020). Selain itu, juga pernah dilakukan kegiatan berupa pelatihan hasil olahan sampah dimasa pandemi Covid-19 oleh Amrizarois Ismail (Ismail et al., 2020).

Daur ulang barang yang sudah tidak terpakai merupakan suatu hal yang sangat bermanfaat. Selain menyelamatkan lingkungan, daur ulang barang yang sudah tidak terpakai juga dapat menghasilkan suatu karya yang menarik, seperti hiasan. Selain itu, dapat juga untuk menghasilkan pendapatan tambahan. Pemanfaatan sampah anorganik, dapat juga dirubah menjadi suatu kerajinan tangan yang mempunyai nilai jual (Chairani \& Sulyono, 2017). Hal ini tentunya dapat menjadi solusi untuk meningkatkan perekomian.

Pernah dilakukan suatu penelitian tentang dampak sosial dan dampak ekonomi dari daur ulang sampah plastik, yaitu memberikan hasil bahwa kegiatan tersebut bermanfaat baik secara sosial maupun dalam perekonomian masyarakat (Linda, 2016).

Daur ulang barang tidak terpakai yang sering dijumpai antara lain adalah daur ulang kertas, botol, plastik, dan lain-lain. Studi tentang limbah kertas dari kantor, sekolah, serta rumah sakit di Kota Padang pernah dipaparkan oleh Rizki Aziz dan Silvia Nitri (Aziz \& Nitri, 2018). Daur ulang atau pemanfaatan dari minyak bekas pakai, atau minyak jelantah, juga pernah dilakukan oleh Wahyuni dan Wulandari. Minyak jelantah tersebut diubah menjadi sabun cuci (Wahyuni \& Wulandari, 2020).

Kreasi bunga dapat dibuat dari berbagai macam bahan berbahan dasar plastik yang sudah tidak terpakai. Baik dari botol plastik, gelas plastik, sampai dengan plastik kresek. Hasilnya pun dapat dikatakan indah dan dapat digunakan sebagai hiasan ruangan.

Botol yakult maupun sedotan plastik merupakan barang-barang yang mudah diperoleh di daerah perkotaan, termasuk di area perumahan atau daerah pemukiman padat penduduk. Semakin banyak konsumsi minuman yakult, maka semakin 
100 Penyuluhan Pembuatan Kreasi Bunga dari Botol Yakult dan Sedotan Plastik - Fita Widiyatun, Sri Endang Wahyuni

DOI: https://doi.org/10.31004/abdidas.v2i1.224

banyak juga botol yakult terbuang yang dihasilkan. Begitu juga dengan sedotan plastik. Pada umumnya sedotan plastik hanya digunakan sekali pakai saja. Sering kita menemukan sedotan plastik di warung-warung, dipakai sekali setelah itu dibuang.

Kegiatan pengabdian kepada masyarakat dilakukan pada warga ibu-ibu PKK Perumahan Permata Cimanggis, Cluster Mirah, RW 19. Pemilihan lokasi ini, karena tim pengabdian kepada masyarakat ingin memberikan kegiatan serta ilmu yang bermanfaat yang dapat menambah kreativitas warganya.

Tujuan dari kegiatan abdimas ini adalah untuk melakukan penyuluhan berupa pengolahan botol yakult dan sedotan plastik, untuk mengubah sampah plastik menjadi hiasan yang menarik, yaitu kreasi bunga. Kreasi bunga yang dibuat yaitu bunga lili, bunga tulip, serta pohon kelapa. Harapan dari kegiatan ini adalah peserta kegiatan dapat mengaplikasikan ilmu yang diperoleh, agar lebih kreatif dalam memanfaatkan barang tidak terpakai di sekitarnya untuk menjadi hiasan atau barang yang lebih bernilai.

\section{METODE}

Program pengabdian kepada masyarakat bermitrakan ibu-ibu PKK dari Cluster Mirah, RW 19, Perumahan Permata Cimanggis, Tapos, Depok, Jawa Barat. Sasaran dari kegiatan ini adalah ibuibu PKK, tetapi tidak menutup kemungkinan apabila ada bapak-bapak yang ikut serta berpartisipasi menjadi peserta dalam kegiatan ini. Kegiatan ini juga terbuka untuk umum, meskipun bukan warga dari Perumahan Permata Cimanggis,
Cluster Mirah, RW 19, dapat mengikuti kegiatan ini. Keseluruhan kegiatan dilakukan dari bulan Maret sampai dengan bulan Agustus 2020. Keseluruhan kegiatan tersebut meliputi perizinan, persiapan alat dan bahan, persiapan materi pelatihan (berupa brosur dan video), persiapan peralatan yang digunakan untuk pelatihan online, sampai dengan pembuatan laporan kegiatan abdimas. Untuk hari dan tanggal penyuluhannya, dilakukan pada hari Sabtu tanggal 4 Juli 2020.

Alat dan bahan yang digunakan untuk pembuatan kreasi bunga, di antaranya adalah botol yakult, sedotan plastik, kawat, gunting, lem tembak, kapas/tissue, putik bunga, carter, kantong plastik berwarna merah, benang, isolasi bening, dll. Dari alat dan bahan di atas, dibuat kreasi bunga lili, bunga tulip, dan pohon kelapa.

Kegiatan pelatihan dilakukan secara online dengan menggunakan aplikasi Zoom. Pada saat penyuluhan berlangsung, dilakukan pemutaran video dan pemberian materi berupa brosur tata cara pembuatan kreasi bunga dari botol yakult dan sedotan plastik. Sebagai evaluasi kegiatan, diberikan waktu tanya jawab setelah kegiatan berlangsung.

\section{HASIL DAN PEMBAHASAN}

Telah dilakukan program kegiatan pengabdian kepada masyarakat tentang pemanfaatan botol yakult, maupun sedotan plastik untuk diubah menjadi kreasi bunga. Kegiatan ini diawali dengan pengurusan perizinan, persiapan alat dan bahan, persiapan materi, pelaksanaan, dan diakhiri dengan pembuatan laporan. 
101 Penyuluhan Pembuatan Kreasi Bunga dari Botol Yakult dan Sedotan Plastik - Fita Widiyatun, Sri Endang Wahyuni

DOI: https://doi.org/10.31004/abdidas.v2i1.224

Awalnya kegiatan pengabdian kepada masyarakat ini akan dilakukan secara offline (tatap muka secara langsung), tetapi karena mulai bulan Maret 2020 Indonesia mengalami pandemi Covid 2019, sehingga kegiatan abdimas dilakukan secara online. Kegiatan dilakukan dengan menggunakan aplikasi Zoom. Penyuluhan sendiri dilakukan pada tanggal 4 Juli 2020, dihadiri oleh 18 peserta dan 2 tim abdimas. Terdapat warga yang tidak dapat mengikuti kegiatan ini, dikarenakan waktu kegiatan di hari Sabtu, yaitu weekend. Dimana, hari Sabtu adalah hari keluarga untuk mereka. Selain itu, pada kegiatan abdimas ini, kami tidak menutup kemungkinan apabila ada warga dari luar/umum yang ingin ikut serta bergabung dalam kegiatan ini.

Pada kegiatan ini, kreasi bunga yang dibuat dari botol yakult dan sedotan plastik adalah bunga lili, bunga tulip, dan pohon kelapa. Seperti ditunjukkan pada gambar 1 dan gambar 2.

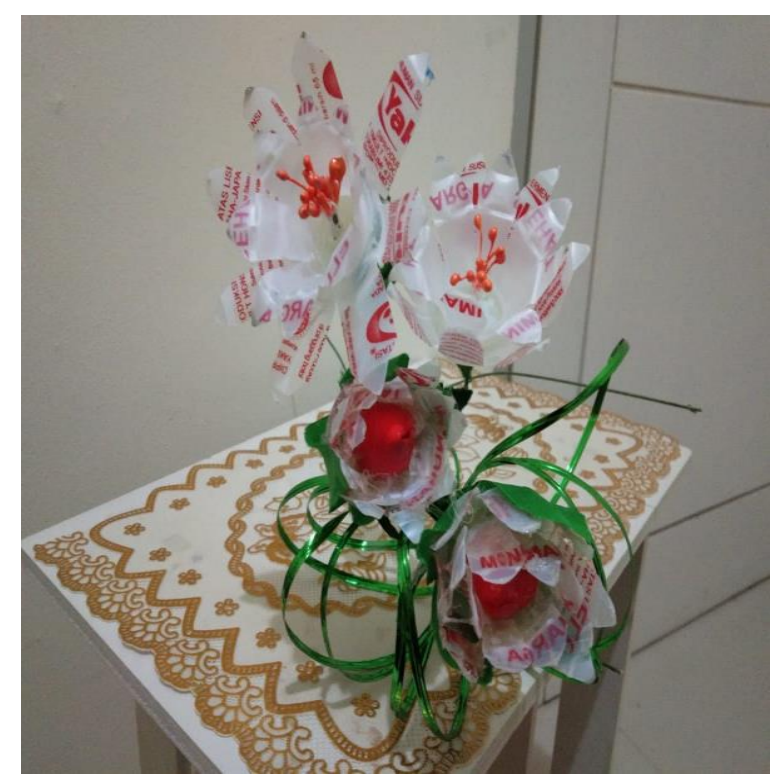

Gambar 1. Kreasi Bunga Tulip dan Bunga Lili dari Botol Yakult.

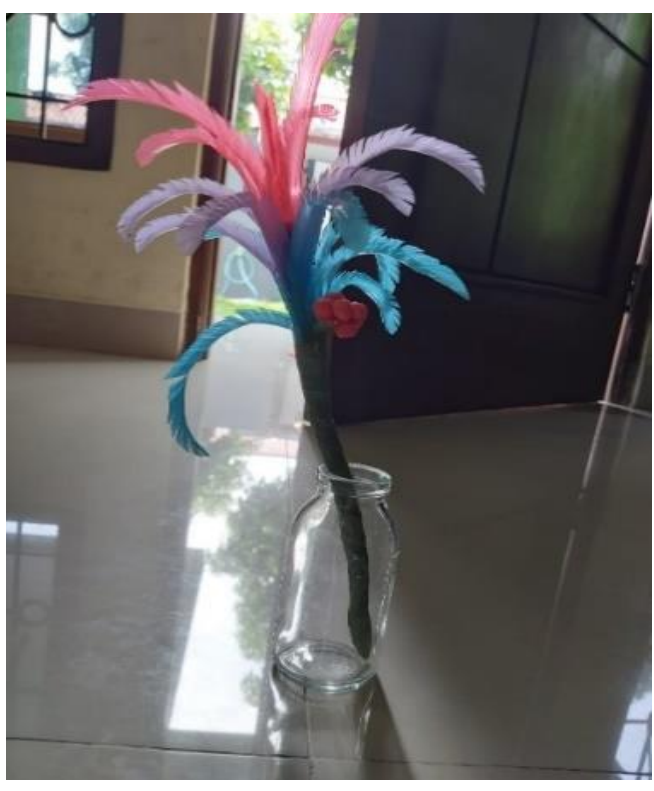

Gambar 2. Kreasi Pohon Kelapa dari Sedotan Plastik.

Sebagai bahan penunjang kegiatan abdimas yang dilakukan secara online, kami membuat brosur yang berisikan tata cara atau langkahlangkah pembuatan kreasi bunga. Langkahlangkah tersebut seperti ditunjukkan pada gambar 4 dan gambar 5, dalam bentuk file .pdf kami bagikan ke peserta. Selain itu, kami juga membuat video tutorial dalam format .mp4 untuk langkahlangkah pembuatan kreasi bunga tersebut. Terdapat dua video tutorial, berdurasi 7 menit dan berdurasi 24 menit. Video tersebut juga kami bagikan ke peserta saat kegiatan abdimas berlangsung.

Susunan acara kegiatan diawali dengan pembukaan dan doa, kemudian sambutan dari Ketua RW setempat yaitu Bapak Imam Budiman. Selanjutnya demo pembuatan kreasi bunga dengan video yang telah dibuat. Selain itu, tim juga share screen langkah-langkah pembuatan kreasi bunga. Seperti ditunjukkan pada gambar 3. 
102 Penyuluhan Pembuatan Kreasi Bunga dari Botol Yakult dan Sedotan Plastik - Fita Widiyatun, Sri Endang Wahyuni

DOI: https://doi.org/10.31004/abdidas.v2i1.224

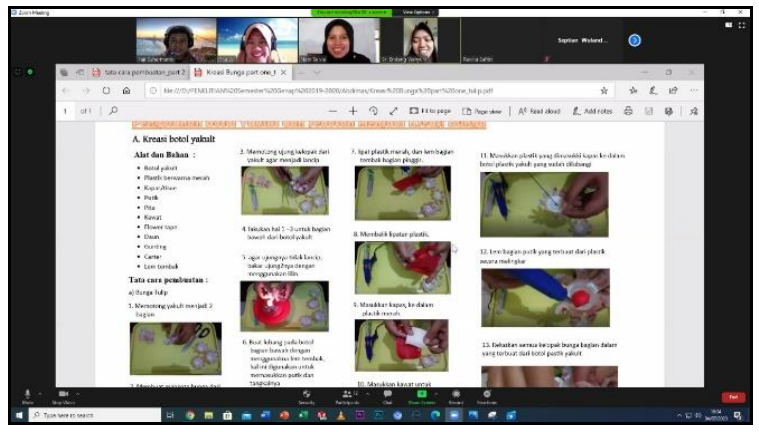

Gambar 3. Share screen tatacara pembuatan kreasi bunga.

Kegiatan pengabdian kepada masyarakat ini telah berjalan dengan baik dan lancar. Tujuan dari kegiatan yaitu melakukan penyuluhan membuat kreasi bunga lili, tulip, dan pohon kelapa dari botol yakult dan sedotan plastik telah tercapai dan dilaksanakan dengan baik. Sesi terakhir dari kegiatan, diberikan waktu untuk tanya jawab dari peserta. Pada sesi ini, peserta tidak memberikan pertanyaan tentang cara pembuatan kreasi bunga yang dilakukan. Hal ini karena, di dalam video pembuatan telah dijelaskan dengan tahapan yang runtut dan baik. Selain itu, peserta juga diperbolehkan bertanya, apabila ada pertanyaan tentang kegiatan ini setelah kegiatan selesai dilaksanakan. Tetapi, juga tidak terdapat pertanyaan dari peserta berkaitan dengan tata cara pembuatan kreasi bunga dengan menggunakan botol yakult maupun sedotan plastik. Sehingga dapat disimpulkan, peserta paham dengan cara pembuatannya.

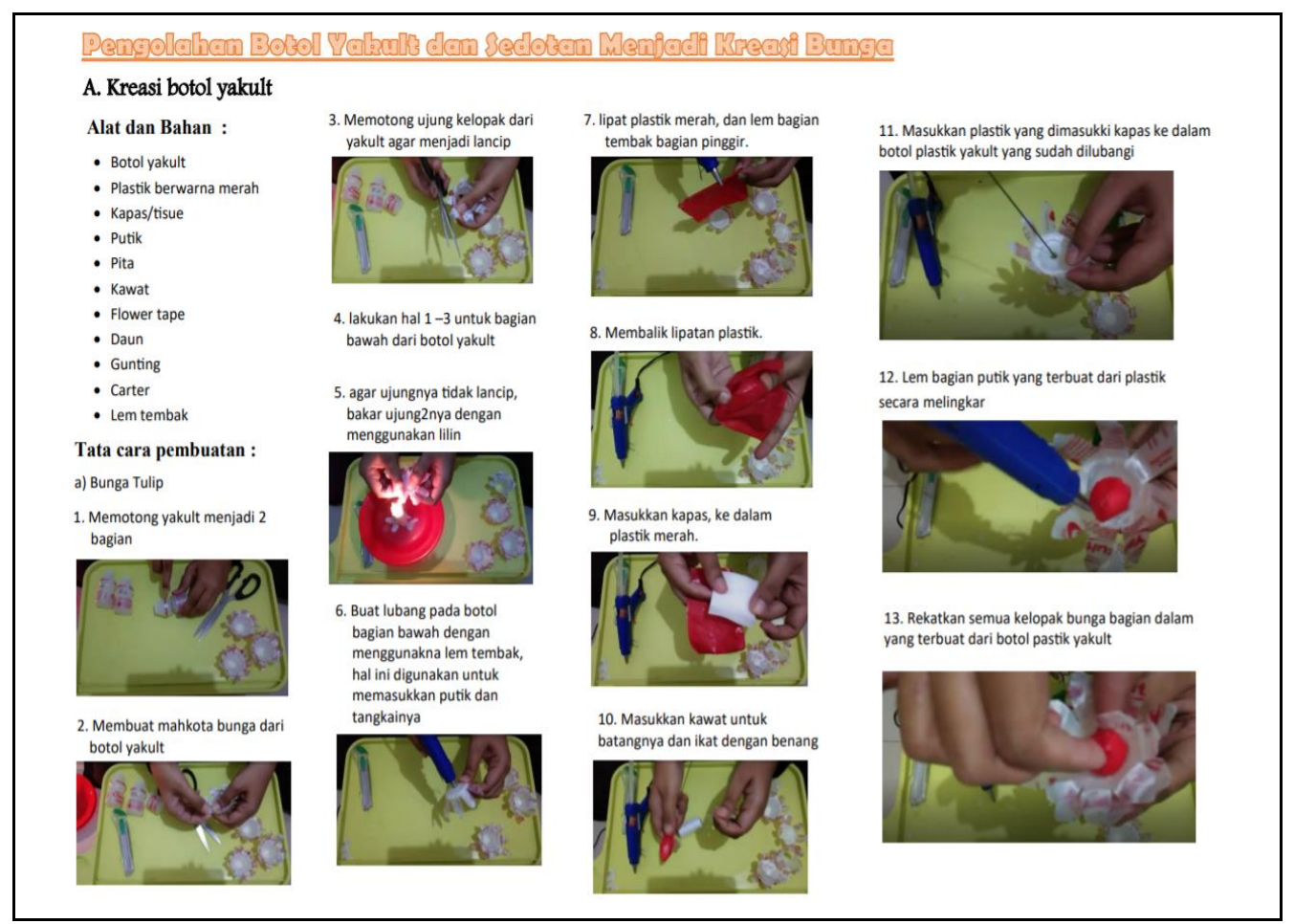

(a) 
103 Penyuluhan Pembuatan Kreasi Bunga dari Botol Yakult dan Sedotan Plastik - Fita Widiyatun, Sri Endang Wahyuni

DOI: https://doi.org/10.31004/abdidas.v2i1.224

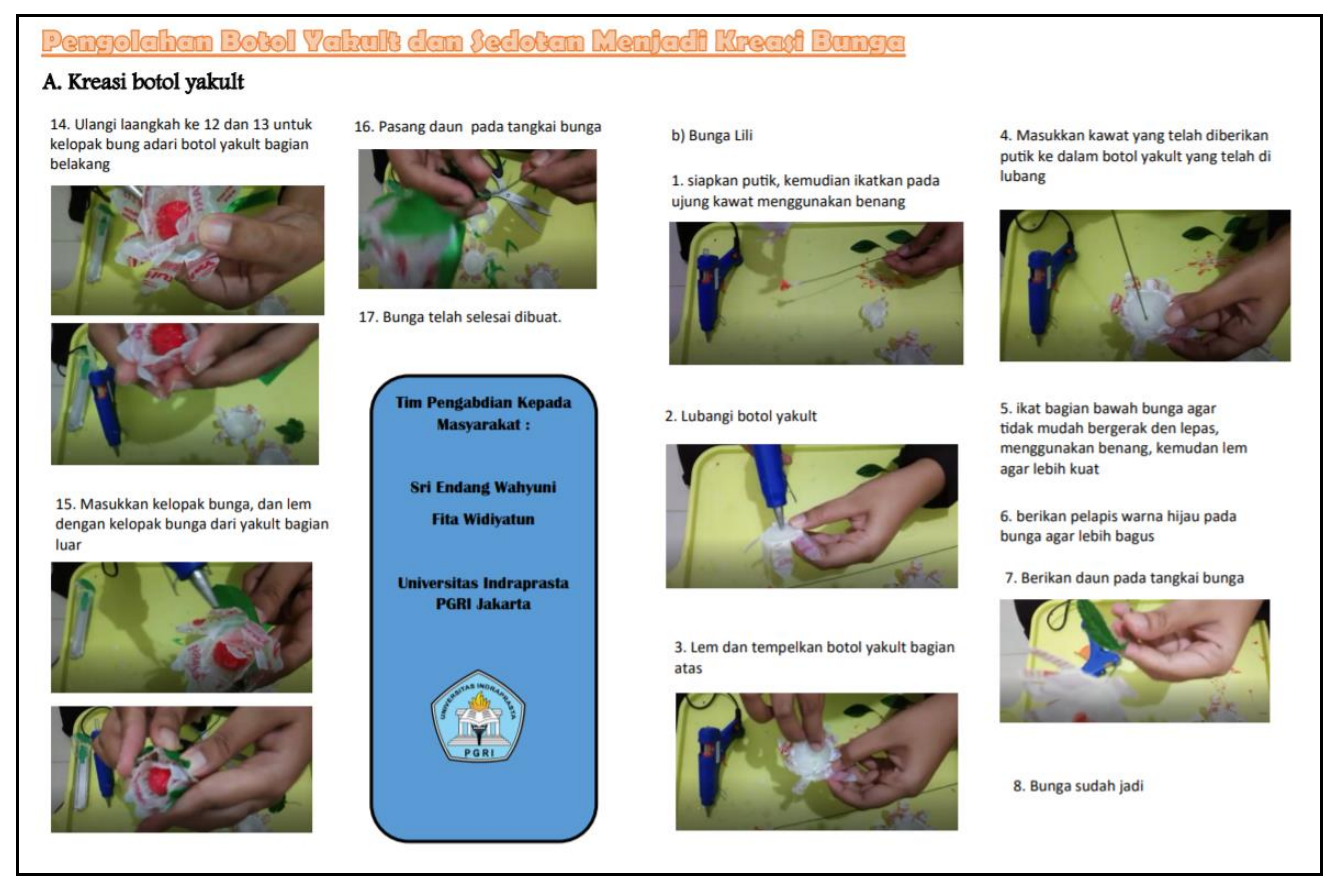

(b)

Gambar 4. Tata Cara Pembuatan Kreasi Bunga Tulip dan Lili dengan Menggunakan Botol Yakult. (a) Pembuatan Bunga Tulip, (b) Lanjutan Pembuatan Bunga Tulip Dan Pembuatan Bunga Lili.

Peserta menyatakan antusias dalam kegiatan yang diikuti, serta berharap ada kegiatan serupa lainnya pada waktu mendatang. Peserta juga senang dengan diadakannya kegiatan seperti ini, karena menambah wawasan dalam berkarya.
Manfaat dari kegiatan ini adalah peserta kegiatan semakin bertambah wawasan tentang membuat kreasi bunga dengan botol yakult dan sedotan plastik.

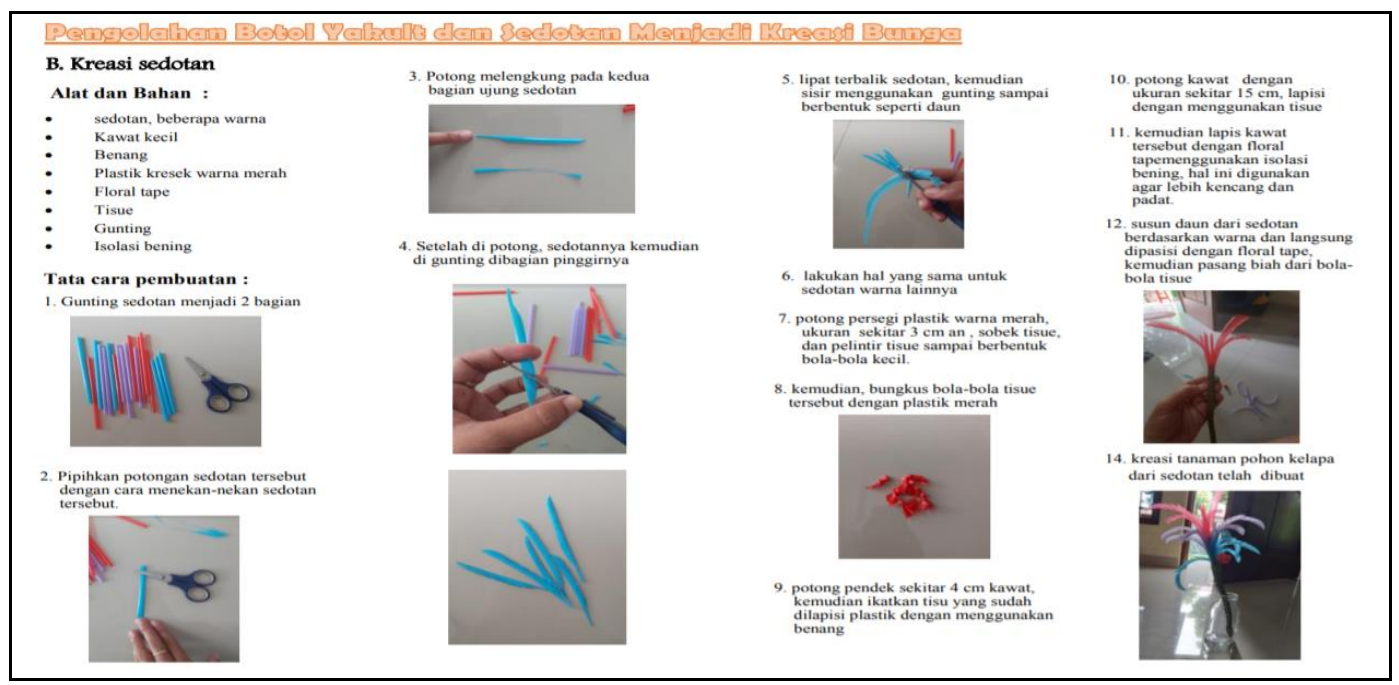

Gambar 5. Tata Cara Pembuatan Kreasi Pohon Kelapa Menggunakan Sedotan Plastik. Diawali dengan Alat dan Bahan yang Dibutuhkan Beserta Langkah-Langkah dalam Pembuatan Pohon Kelapa. 
104 Penyuluhan Pembuatan Kreasi Bunga dari Botol Yakult dan Sedotan Plastik - Fita Widiyatun, Sri Endang Wahyuni

DOI: https://doi.org/10.31004/abdidas.v2i1.224

\section{SIMPULAN}

Kegiatan pengabdian kepada masyarakat berupa pelatihan pengolahan limbah plastik botol yakult dan sedotan menjadi kreasi bunga telah dilaksanakan dengan baik dan lancar. Kegiatan ini merupakan kegiatan yang menarik dan menambah wawasan bagi peserta untuk dapat lebih memanfaatkan botol yakult bekas dan sedotan plastik diolah menjadi kreasi bunga lili, tulip, dan pohon kepala.

\section{UCAPAN TERIMA KASIH}

Bapak Imam Budiman S.Kom, selaku Ketua RW Cluster Mirah, RW 19, Perumahan Permata Cimanggis, Tapos, Depok, Jawa Barat.

\section{DAFTAR PUSTAKA}

Aziz, R., \& Nitri, Si. (2018). Studi Daur Ulang Sampah Kertas dari Sumber Institusi di Kota Padang. Jurnal Dampak, Vol. 15(No. 2), Hal. 77-81.

Chairani, \& Sulyono. (2017). Pemberdayaan Kelompok Ibu-ibu rumah Tangga Melalui Pemanfaatan Sampah Anorganik Menjadi Kerajinan Tangan. Ethos, 5(2), 159-166.

Harmawati, Anwar, A. S., \& Prawiyogi, A. G. (2020). Sosialisasi Perilaku Hidup Bersih dan Sehat dengan Menerapkan Metode 3R (Reduce, Reuse, Recycle). Abdidas, 1(4), 284-288.

Ismail, A., Susilorini, M. R., Wardhani, D. K., \& Angghita, L. J. (2020). Adaptasi Pendampingan Pengelolaan Sampah di Masa Pandemi Covid-19 melalui Web Training Kreatifitas Produk Olahan Sampah. Jurnal Abdidas, 1(3), 165-171.

Linda, R. (2016). Pemberdayaan Ekonomi Kreatif Melalui Daur Ulang Sampah Plastik (Studi Kasus Bank Sampah Berlian Kelurahan Tangkerang Labuai). Jurnal Al-Iqtishad, 12(1), https://doi.org/10.24014/jiq.v12i1.4442

Putra, H. P., \& Yuriandala, Y. (2010). Studi Pemanfaatan Sampah Plastik Menjadi Produk dan Jasa Kreatif. Jurnal Sains \&Teknologi Lingkungan, 2(1), 21-31. https://doi.org/10.20885/jstl.vol2.iss1.art3

Satori, M., Prastyaningsih, E., Srirejeki, Y., Ulfah, T. H. N., Nurmalasari, N. R., \& Nuralam, I. (2018). Pengolahan Sampah Organik Rumah Tangga Dengan Metode Bata Terawang. ETHOS (Jurnal Penelitian Dan Pengabdian), $6(1)$, 135-145. https://doi.org/10.29313/ethos.v6i1.3559

Wahyuni, S. E., \& Wulandari, S. (2020). Pemanfaatan Minyak Jelantah Hasil Pemurnian Arang Kayu untuk Sabun Cuci Padat. Ethos, 8(2), 265-270. 